\title{
PENGUASAAN DIKSI SEBAGAI PENGUATAN SOFT SKILL KOMUNIKASI DAN NEGOSIASI DALAM KOMPETENSI AUDITOR BAGI MAHASISWA AKUNTANSI
}

\author{
Ririn Sri Kuntorini \\ Program Studi Akuntansi \\ Fakultas Ekonomi dan Bisnis \\ Universitas Islam Bandung \\ kuntorini.ririnsri@gmail.com
}

\begin{abstract}
The opportunities and challenges of the 4.0 industrial revolution era make competent accounting students not only need to rely on hard skills, at least they need soft skills development, including effective communication and negotiation. The method used in this research is descriptive qualitative method that describes, tells, and explains the results of research to describe how the use of diction in accounting students' papers as an indicator of the importance of soft skills in effective communication and negotiation used to analyze data. Jobs that are in great demand, namely auditors and accountants for accounting graduates rely on soft skills, are hampered by many students who have difficulty writing scientific papers or presentations related to accounting and auditing. This study aims to determine the mastery of diction as a strengthening of soft communication skills in auditor competence for accounting students. Higher education expects students to be able to express their thoughts orally or in writing with good and correct Indonesian rules, making diction, one of the areas of study of Indonesian Language courses, must be mastered in order to communicate and negotiate. The result of this research is that good and strong mastery of diction will strengthen the soft skills of effective communication and negotiation in the competence of auditors for accounting students in the workforce.
\end{abstract}

Keywords: Soft Skills, Effective Communication, Negotiation, Auditors.

\begin{abstract}
Abstrak
Peluang dan tantangan era revolusi industri 4.0 menjadikan mahasiswa akuntansi yang kompeten tidak cukup mengandalkan hard skill saja, setidaknya perlu pengembangan soft skill, antara lain komunikasi efektif dan negosiasi. Metode yang digunakan dalam penelitian ini ialah metode kualitatif deskriptif yang menggambarkan, menceritakan, dan menjelaskan hasil penelitian untuk mendekripsikan bagaimana penggunaan diksi dalam karya tulis mahasiswa akuntansi sebagai indikator pentingnya soft skill komunikasi efektif dan negosiasi yang digunakan untuk menganalisis data. Lapangan kerja yang
\end{abstract}


banyak diminati yaitu auditor dan akuntan bagi sarjana akuntansi mengandalkan kemampuan soft skill banyak terkendala dengan banyaknya mahasiswa yang mengalami kesulitan pada saat menulis karya ilmiah atau presentasi yang berhubungan dengan akuntansi dan audit. Penelitian ini bertujuan mengetahui penguasaan diksi sebagai penguatan soft skill komunikasi dalam kompetensi auditor bagi mahasiswa akuntansi. Pendidikan tinggi mengharapkan mahasiswa mampu mengungkapkan pikiran secara lisan maupun tulisan dengan kaidah bahasa Indonesia yang baik dan benar, menjadikan diksi salah satu bidang kajian mata kuliah Bahasa Indonesia wajib dikuasai agar dapat berkomunikasi dan bernegosiasi. Hasil penelitian ini adalah penguasaan diksi yang baik dan kuat akan menguatkan soft skill komunikasi efektif dan negosiasi dalam kompetensi auditor mahasiswa akuntansi di lapangan kerja.

\section{Kata Kunci: Soft Skill, Komunikasi Efektif, Negosiasi, Auditor.}

\section{PENDAHULUAN}

Di era Revolusi Industri 4.0 ini banyak informasi yang dapat diperoleh, meskipun ada yang benar dan ada yang tidak, namun setidaknya insan akademis sudah terbiasa untuk menganalisis serta menyaring melalui pembuktian. Berdasarkan hasil survei yang dilakukan oleh quipper campus terdapat 12 jurusan yang menjamin lulusannya tidak menganggur, dimana 5 jurusan teratas adalah keuangan dan perbankan, akuntansi, teknik mesin, administrasi bisnis, dan manajemen (quipper.com, 1 September 2020). Program studi Akuntansi menempati urutan kedua, artinya termasuk favorit dengan alasan bahwa hampir semua unit usaha dalam dunia bisnis membutuhkan akuntan. Tugas akuntan ialah menghitung pemasukan dan juga pengeluaran yang ada di perusahaan setiap harinya. Seperti diketahui, tanpa pencatatan keuangan yang baik, perusahaan dapat mengalami kerugian dan akhirnya perusahaan tersebut bangkrut. Oleh karena itu, akuntan yang lulusan akuntansi pasti selalu dibutuhkan perusahaan.

Dalam sebuah pemeringkatan, semakin tinggi peringkat di sebuah perguruan tinggi maka relevansi dengan lapangan kerja pun sama, semakin tinggi pula peluang dan tantangannya. Hal tersebut juga didukung adanya survei yang dilakukan oleh Nevada (gokampus.com, April 2021) yang menyatakan 8 pekerjaan sarjana akuntansi yang paling banyak dicari, yaitu: Akuntansi Publik, Akuntansi Privat, Financial Analyst, Auditor Internal, Konsultan Pajak, Perencana Keuangan, Accounts Payable/Recievable Clerk, Credit Analyst dengan besaran pendapatan minimalnya 5 juta rupiah. 
Peluang yang dihadapkan pada mahasiswa akuntansi tersebut tidak semua dapat dilakukan dengan mudah. Pada kenyataannya masih banyak mahasiswa yang tidak mampu menyampaikan laporan analisis dalam tugas kuliah dengan memenuhi standar pelaporan dengan benar karena kesulitan menemukan kata yang tepat. Bahkan dari penelitian Hernawati, Maemunah, Kuntorini (2021) dari 91 responden mahasiswa yang mengambil mata kuliah Audit Internal, 90 orang menyatakan bahwa pelatihan yang diharapkan bisa mereka ikuti adalah Public Speaking sebagai urutan pertama dibanding pelatihan dengan bidang kajian ilmu akuntansi lainnya. Hal tersebut memperlihatkan bahwa mahasiswa akuntansi merasa kemampuan berbahasa mereka akan dianggap baik apabila menguasai public speaking sebagai pemenuhan soft skill diri dalam menghadapi peluang kerja setelah lulus.

Penelitian Palupi (2011) tentang upaya membangun karakter (soft skill) mahasiswa menyatakan bahwa kontribusi soft skill yang dibutuhkan pada dunia kerja cukup tinggi sehingga dibutuhkan SDM/mahasiswa yang memiliki karakter (soft skill) kuat. Dukungan lainnya adalah penelitian Solin (2010) membuktikan bahwa bahasa Indonesia berperan membetuk karakter dan kepribadian Indonesia melalui penggunaan bahasa Indonesia seperti berbicara, mendengar, membaca, dan menulis dengan menggunakan bahasa Indonesia yang benar. Semakin intensif penggunaan bahasa dan semakin teliti dan benar pilihan bahasa yang digunakan, diyakini semakin tinggi karakter dan kepribadian orang yang menggunakannya. Adapun pengaruh komunikasi terhadap pemahaman akuntansi dibuktikan dengan adanya hasil analisis penelitian Riswanti (2010: 1) bahwa kemampuan komunikasi, berpikir kritis, dan kepribadian berpengaruh terhadap pemahaman akuntansi. Sedangkan variabel berpikir kritis berpengaruh secara signifikan terhadap pemahaman akuntansi mahasiswa. Pemahaman akuntansi mahasiswa S1 Akuntansi dipengaruhi oleh kemampuan komunikasi, berpikir kritis, dan kepribadian sebesar 68,4 \%.

Fuadiyah dan Sukesti (2013: 43) membuktikan bahwa audit pada saat ini menjadi bagian yang penting dalam dunia akuntansi. Selain pemahaman umum atas pentingnya fungsi audit, peningkatan atas keberadaan auditor dan lembaganya juga menambah pemahaman umum terhadap audit. Lebih lanjut lagi, tuntutan-tuntutan hukum yang biasanya dihadapi oleh auditor dan kerugian keuangan yang terkait dengan tuntutan tersebut memunculkan berbagai dimensi keperilakuan pada diri auditor, khususnya 
aspek-aspek yang terkait dengan proses pengambilan keputusan dan aktivitas auditor dalam mempertimbangkan sesuatu sebelum mengambil keputusan.

Untuk memperoleh lulusan mahasiswa yang berkualitas, peran dosen tidaklah penting bila tidak diimbangi dengan dorongan dari dalam mahasiswa itu sendiri. Secara umum tujuan motivasi adalah untuk menggerakkan atau menggugah seseorang agar timbul keinginan dan kemauannya untuk melakukan sesuatu sehingga dapat memperoleh hasil atau mencapai tujuan tertentu (Purwanto dalam Fuadiyah dan Sukesti, 2013: 43). Menurut Sadirman, motivasi adalah proses yang memberi semangat, arah, dan kegigihan perilaku. Artinya, perilaku yang memiliki motivasi adalah perilaku yang penuh energi, terarah, dan bertahan lama (Fuadiyah dan Sukesti, 2013: 43).

Penelitian Fuadiyah dan Sukesti (2013: 43) juga membuktikan bahwa kemampuan komunikasi juga dianggap sebagai faktor penting untuk mencapai kesuksesan dalam bidang akuntansi khususnya auditing. Kemampuan komunikasi seseorang dapat meningkatkan produktivitas individu maupun kelompok. Setiap orang memiliki kecenderungan terhadap gaya komunikasi tertentu. Hal ini dipengaruhi oleh perpaduan antara hereditas dan faktor lingkungan seseorang.

Dalam penelitian ini penulis mengambil fenomena bahwa masih banyaknya kesalahan penggunaan diksi pada mahasiswa akuntansi dalam penulisan karya tulis ilmiah. Mahasiswa akuntansi yang akan berprofesi sebagai auditor dan akuntan seharusnya memiliki kompetensi yang tinggi agar mampu bersaing menggunakan penguatan komunikasi dan negosiasi yang memenuhi standar IAI melalui kemampuan penguasaan diksi yang baik. Berdasarkan latar belakang tersebut maka dilakukan penelitian terhadap salah satu kunci penguatan kompetensi auditor dan akuntan yaitu penguasaan diksi sebagai penguatan soft skill komunikasi dan negosiasi dalam kompetensi auditor bagi mahasiswa akuntansi.

\section{LANDASAN TEORI}

\subsection{Mata Kuliah Bahasa Indonesia}

Keputusan Direktur Jenderal Pendidikan Tinggi Kementerian Pendidikan dan Kebudayaan Republik Indonesia Nomor 84/E/Kpt/2020 tentang Pedoman Pelaksanaan Mata Kuliah Wajib pada kurikulum pendidikan tinggi menyatakan mata kuliah Bahasa Indonesia merupakan pendidikan yang menjadikan mahasiswa mampu 
mengungkapkan pikiran secara lisan maupun tulisan dengan kaidah bahasa Indonesia yang baik dan benar, menjadikan Bahasa Indonesia sebagai penghela ilmu pengetahuan dan menjadi alat pemersatu bangsa.

Adapun substansi mata kuliah Bahasa Indonesia meliputi: (1) hakikat bahasa Indonesia sebagai bahasa persatuan dan bahasa negara; (2) mengeksplorasi teks dalam kehidupan akademik (penanaman nilai dan hakikat bahasa Indonesia sebagai penghela ilmu pengetahuan); (3) menjelajah dunia pustaka; (4) mendesain proposal penelitian dan proposal kegiatan; (5) melaporkan hasil penelitian dan hasil kegiatan; dan (6) mengaktualisasikan diri dalam artikel ilmiah.

Bahasa sebagai alat komunikasi merupakan bagian utama dalam kehidupan manusia, mahasiswa salah satunya yang paling banyak dituntut mampu berbahasa Indonesia dengan baik dan benar dalam setiap praktik perkuliahan. Di samping itu, mahasiswa yang nantinya akan menjadi seorang sarjana pun dituntut mampu menggunakan kemampuan bahasanya sebagai alat dalam melakukan kinerja sesuai standar di lapangan kerjanya.

Dalam suatu percakapan, pembicara tidak selalu mengeksplisitkan maksud yang diinginkan kepada pendengar. Apabila pendengar memahami maksud yang diinginkan oleh pembicara, percakapan dapat berjalan dengan lancar. Yang menjadi persoalan adalah ketika pendengar tidak memahami maksud yang diinginkan oleh pembicara. Percakapan yang maksudnya diimplisitkan akan membuat komunikasi tidak berlangsung dengan baik karena komunikasi akan berlangsung selama ada kesamaan makna yang dipercakapkan (Kuntorini, Djajasudarma, Wahya, 2013: 2).

Berbagai media yang digunakan sebagai sarana penyampaian informasi, baik secara lisan maupun tertulis, sampai atau tidaknya pesan yang hendak disampaikan bergantung pada bahasa yang digunakan. Penggunaan bahasa yang sederhana dan mudah dipahami akan menjadikan pesan lebih mudah diterima karena bahasa adalah alat komunikasi (Kuntorini dan Pradana, 2014: 228).

Dari keempat jenis keterampilan berbahasa, yaitu menyimak, berbicara, membaca, dan menulis maka semua keterampilan tersebut didasarkan pada diksi. Diksi adalah pilihan kata dan kejelasan lafal yang tepat untuk mengungkapkan gagasan, ide, atau pikiran. Penggunaan diksi yang baik akan menambah keterampilan berbicara seseorang 
karena diksi dapat menentukan kata yang tepat digunakan untuk situasi dan kondisi pembicaraan yang berlangsung.

\subsection{Pengertian, Ketepatan, Kesesuaian, dan Indikator Penguasaan Diksi}

Menurut Kamus Besar Bahasa Indonesia (2006: 264), diksi adalah pilihan kata yang tepat dan selaras (dalam penggunaannya) untuk mengungkapkan gagasan sehingga diperoleh efek tertentu (seperti yang diharapkan). Pilihan kata atau diksi sebenarnya bukan saja dipergunakan untuk menyatakan kata-kata mana yang dipakai untuk mengungkapkan suatu ide atau gagasan, tetapi juga meliputi persoalan fraseologi, gaya bahasa, dan ungkapan (Keraf, 2010: 22-23).

Selanjutnya Keraf (2010: 24) menurunkan tiga kesimpulan utama mengenai diksi. Pertama, pilihan kata atau diksi mencakup pengertian kata-kata mana yang dipakai untuk menyampaikan suatu gagasan, bagaimana membentuk pengelompokkan kata-kata yang tepat atau menggunakan ungkapan kata yang tepat, dan gaya mana yang paling baik digunakan dalam situasi. Kedua, pilihan kata atau diksi adalah kemampuan membedakan secara tepat nuansa-nuansa makna dari gagaasan yang ingin disampaikan, dan kemampuan untuk menemukan bentuk yang sesuai (cocok) dengan situasi dan nilai rasa yang dimiliki kelompok masyarakat pendengar. Ketiga, pilihan kata yang tepat dan sesuai hanya dimungkinkan oleh penguasaan sejumlah besar kosakata atau perbendaharaan kata bahasa itu.

Untuk ketepatan diksi, seseorang harus cermat dalam pemilihan kata agar maksud dari pembicaraan dapat diterima selain juga harus menguasai pokok pembicaraan, yaitu: (1) membedakan secara cermat denotasi dari konotasi; (2) membedakan dengan cermat kata-kata yang hampir bersinonim; (3) membedakan kata-kata yang mirip dalam ejaannya; (4) menghindari kata-kata ciptaan sendiri; (5) waspada terhadap penggunaan akhiran asing; (6) kata kerja menggunakan kata depan yang digunakan secara idiomatis; (7) membedakan kata umum dan kata khusus; (8) mempergunakan kata-kata indria yang menunjukkan persepsi yang khusus; (9) memperhatikan perubahan makna yang terjadi pada kata-kata yang sudah dikenal; (10) memperhatikan kelangsungan pilihan kata (Keraf, 2010: 88-89).

Selanjutnya, dalam pendayagunaan kata-kata adalah adanya kecocokan atau kesesuaian. Beberapa hal yang perlu diketahui agar kata-kata yang dipergunakan tidak mengganggu suasana dan tidak akan menimbulkan ketegangan antara pembicara dengan 
pendengar adalah: (1) menghindari sejauh mungkin bahasa atau unsur substandar dalam suatu situasi yang formal; (2) menggunakan kata-kata ilmiah dalam situasi yang khusus saja; (3) menghindari pemakaian kata-kata slang; (4) menghindari ungkapan-ungkapan usang (idiom yang mati); (5) menjauhkan kata-kata atau bahasa yang artifisial (Keraf, 2010: 103-104).

Berdasarkan ketepatan dan kesesuaian diksi, indikator penguasaan diksi dibagi ke dalam: (1) membedakan kata denotatif dan konotatif; (2) menentukan kata yang bersinonim; (3) membedakan kata umum dan kata khusus; (4) tepat dalam menggunakan kata indria; (5) membedakan kata ilmiah dan kata populer (Keraf, 2010: 105-106).

Untuk penguasaan diksi dalam tata cara menyampaikan laporan sebagai bagian dari tugas seorang auditor atau akuntan, Tarigan (2015: 30) menjelaskan bahwa informative speaking dilaksanakan jika seseorang berkeinginan untuk: (1) memberi atau menanamkan pengetahuan; (2) menetapkan atau menentukan hubungan-hubungan antara benda-benda; (3) menerangkan atau menjelaskan sesuatu proses; (4) menginterpretasikan atau menafsirkan sesuatu persetujuan ataupun menguraikan sesuatu tulisan. Sedangkan pembicaraan yang bersifat informatif didasarkan pada: (1) pengalaman yang harus dihubung-hubungkan; (2) proses yang harus dijelaskan; (3) tulisan yang harus dijelaskan/dipahami; (4) ide atau gagasan yang harus disingkapkan; serta (5) instruksi atau pengajaran yang harus digambarkan dan diragakan.

\subsection{Pengertian Komunikasi}

Komunikasi menurut KBBI adalah pengiriman dan penerimaan pesan atau berita antara dua orang atau lebih sehingga pesan yang dimaksud dapat dipahami; hubungan; kontak. Komunikasi sebagai satu proses melibatkan: (1) pihak yang berkomunikasi, (2) informasi, dan (3) alat komunikasi.

Proses komunikasi dapat terjadi apabila ada interaksi antarmanusia dan ada penyampaian pesan untuk mewujudkan motif komunikasi. Melalui komunikasi sikap dan perasaan seseorang atau sekelompok orang dapat dipahami oleh pihak lain (Waridah, 2016: 233).

Komunikasi dikatakan efektif apabila orang berhasil menyampaikan apa yang dimaksudkannya atau apabila rangsangan yang disampaikan dan dimaksudkan oleh pengirim atau sumber, berkaitan erat dengan rangsangan yang ditangkap dan dipahami oleh penerima. Jika berbahasa adalah cara berkomunikasi yang mendukung pemenuhan 
salah satu soft skill yang diperlukan, maka berbagai media yang digunakan sebagai sarana penyampaian informasi, baik secara lisan maupun tertulis, sampai atau tidaknya pesan yang hendak disampaikan bergantung pada bahasa yang digunakan. Penggunaan bahasa yang sederhana dan mudah dipahami akan menjadikan pesan lebih mudah diterima karena bahasa adalah alat komunikasi (Kuntorini dan Pradana, 2014: 228).

\subsection{Kompetensi Soft Skills Auditor}

Menurut (DPN IAI, 2016), skill yang harus dimiliki oleh auditor di era revolusi industri 4.0 yang kompeten tidak cukup mengandalkan hard skill saja, setidaknya perlu area pengembangan, antara lain:

1. Meningkatkan soft skill.

a. Interpersonal skills: leadership, motivasi, komunikasi efektif, negosiasi, problem solving, dan lain-lain.

b. Intra-personal skills: integritas, profesional, character building, creative thinking, dan lain-lain.

2. Terus-menerus meningkatkan kompetensi.

Dengan cara pendidikan profesionalisme berkelanjutan, menganalisis big data dalam aktivitas akuntansi menjadi informasi ringkas yang bisa dijadikan dalam pengambilan keputusan bisnis (teoritis analisis dan praktis), menguasai teknologi (pemahaman, fleksibilitas, dan kemampuan beradaptasi)

3. Membangun networking.

Akuntan ke depannya harus mampu mengelola angka bersama dengan manusia, serta membangun networking yang kuat dan luas dengan individu dan institusi.

4. Memiliki sertifikasi akuntan professional.

Akuntan memiliki sertifikasi akuntan yang diakui internasional seperti: ACPA, CGMA, QIA.

5. Memiliki integritas yang tinggi.

Bersaing dengan menjunjung tinggi kejujuran karena industri/pemakai jasa akuntan profesional akan memilih akuntan yang berintegritas.

6. Persiapan mental menjadi player.

Memiliki sikap optimis dalam menghadapi revolusi industri 4.0 dan siap 
bersaing dengan akuntan dan auditor asing.

Diharapkan dengan menganalisis skill-skill yang dibutuhkan mahasiswa akuntansi, untuk ke depannya akan dibuatkan metode atau program peningkatan kapasitas personal maupun institusi, agar dapat meningkatkan kompetensi lulusan akuntansi dan mampu berkompetisi dengan auditor nasional, regional, dan internasional di era revolusi industri 4.0 (Hernawati, Memunah, dan Kuntorini, 2021: 6). Penelitian ini mengkhususkan pada soft skill interpersonal yang menitikberatkan pada komunikasi efektif dan negosiasi yang dapat diperoleh melalui penguatan diksi.

\subsection{Auditor Masa Depan (Akuntan Masa Depan)}

Hard skill merupakan kemampuan dan penguasaan akan suatu bidang yang sudah dipelajari di bangku sekolah, sedangkan soft skill merupakan kemampuan untuk mengelola emosi yang ada di dalam diri sendiri, baik dalam berkomunikasi dan cara untuk bisa bekerja sama dengan baik bersama orang lain. Maka agar seseorang bisa sukses dalam dunia kerja maka kedua aspek tersebut harus dapat berjalan dengan seimbang. Soft skill memegang peran yang cukup penting di tempat kerja. Kurangnya soft skill merupakan faktor yang menyebabkan lulusan tidak dapat memperoleh pekerjaan (Hairi et.al. dalam Hernawati, Maemunah, Kuntorini, 2021: 5).

Di era revolusi industri 4.0, soft skill yang mendominasi kebutuhan di tempat kerja meliputi pengetahuan interpersonal dan intrapersonal, keterampilan dan kemampuan yang berkaitan dengan etika, organisasi personal dan kebiasaan kerja, manajemen waktu, kerja tim dan komunikasi interpersonal, manajemen emosi, kemampuan memecahkan masalah, dan kemampuan dalam belajar (Mc Namara dalam Hernawati, Maemunah, Kuntorini, 2021: 5). Kemampuan interpersonal merupakan kemampuan seseorang untuk mengarahkan diri sendiri, termasuk kemampuan komunikasi secara efektif, menjalani hubungan dengan orang lain dan mampu menyelesaikan masalah (Lindsey dalam Hernawati, Maemunah, Kuntorini, 2021: 5).

Dari hasil observasi dan tabulasi data terhadap lowongan pekerjaan akuntansi spesialisasi untuk pemula di situs Jobstreet, diperoleh adanya 17 kriteria kecakapan yang diungkapkan, yaitu: (1) memiliki pengalaman kerja; (2) memiliki sertifikat Brevet A dan B; (3) memiliki pamahaman terhadap aturan pajak; (4) memiliki kecakapan dalam mengoperasikan program komputer; (5) memiliki kecakapan berkomunikasi; (6) memiliki kecakapan dalam berbahasa asing; (7) memiliki sikap mandiri; (8) memiliki 
inisiatif tinggi; (9) memiliki sikap disiplin; (10) kecakapan dalam kerja sama tim/organisasi; (11) memiliki kesediaan bekerja lembur; (12) memiliki sikap detail dan teliti; (13) memiliki sikap jujur; (14) memiliki sikap bertanggung jawab; (15) memiliki pemahaman akuntansi; (16) memiliki kecakapan menganalisis; (17) memiliki kecakapan dalam menyusun dan mempresentasikan laporan (Dewi dan Dewi, 2020: 267).

\section{METODE PENELITIAN}

Metode yang digunakan dalam penelitian ini ialah metode kualitatif deskriptif dengan menitikberatkan pada metode yang menggambarkan, menceritakan, dan menjelaskan hasil penelitian untuk mendekripsikan bagaimana penggunaan diksi dalam karya tulis mahasiswa akuntansi sebagai indikator pentingnya soft skill komunikasi efektif dan negosiasi yang digunakan untuk menganalisis data dengan cara mendeskripsikan atau menggambarkan data yang telah terkumpul sebagaimana adanya. Data yang diperoleh di lapangan dianalisis dan kemudian digeneralisasi untuk mendapatkan temuan penelitian. Data induktif pada penelitian bahasa merupakan gejala bahasa yang betul-betul digunakan oleh masyarakat penuturnya.

Sumber data yang diperoleh untuk penelitian ini adalah 91 mahasiswa akuntansi yang mengambil mata kuliah audit yang salah satu potensi kerjanya adalah sebagai auditor dan akuntan, diamati dan dicatat dari makalah mahasiswa serta dilanjutkan dengan wawancara terhadap 30 orang di antaranya. Oleh karena itu, penelitian ini bertujuan mengetahui sejauh mana penguasaan diksi sebagai penguatan soft skill komunikasi dan negosiasi dapat menguatkan kompetensi auditor mahasiswa akuntansi.

\section{ANALISIS DAN PEMBAHASAN}

Manusia memiliki sistem kerja dalam dirinya di kehidupannya. Kinerja sistem beserta komponen yang mendukung kehidupan manusia tidak semata-mata didasari oleh keberadaan peralatan yang ada, tetapi dorongan dari manusia untuk mengaktualisasikan kemampuannya. Dorongan dari dalam diri manusia ini disebut dengan kemampuan soft skill. Berdasarkan hasil beberapa jajak pendapat (tracer study) yang dilakukan beberapa perguruan tinggi di Indonesia, kompetensi sarjana di dunia kerja dibagi dua aspek yakni hard skill dan soft skill. Soft skill sangat terkait erat dengan masalah kecerdasan emosi. Kecerdasan emosi merupakan kemampuan seseorang untuk memotivasi diri sendiri, 
bertahan menghadapi frustrasi, mengendalikan dorongan hati dan tidak melebih-lebihkan kesenangan, mengatur suasana hati, dan mampu mengendalikan stress.

Penting bagi mahasiswa untuk memiliki bekal soft skill untuk terjun di dunia kerja setelah menyelesaikan pendidikan di perguruan tinggi. Sarjana siap pakai adalah mahasiswa dengan integritas soft skill yang diperolehnya di kampus melalui mata kuliah dan praktik perkuliahan. Sebagai calon tenaga kerja, ada beberapa soft skill yang harus diperhatikan, antara lain: keterampilan berkomunikasi (communicative skill), keterampilan berpikir dan keterampilan menyelesaikan masalah (thinking skill and problem solving skill), belajar sepanjang hidup dan pengelolaan informasi (life-long learning and information management) keterampilan secara tim (team work skill), keterampilan wirausaha (entrepeneur skill), etika, moral, dan profesionalisme (ethics, moral, and profesionalism), dan keterampilan kepemimpinan (leadership skill). Adapun soft skill untuk calon wirausahawan ialah: communication skills (kemampuan berkomunikasi), marketing skills (kemampuan pemasaran), negotiation skills (kemampuan bernegosiasi), creative (kreatif), relation building (membangun relasi), dan public speaking skills (kemampuan berbicara di depan publik).

Manusia memiliki kemampuan berbahasa yang didasarkan pada penguasaan kunci bahasa yaitu kata. Berkaitan dengan kata, maka diksi adalah kekuatan yang dapat dipergunakan dalam mengelaborasi kemampuan komunikasi seorang mahasiswa. Diksi merupakan pemilihan kata yang paling tepat untuk menyampaikan suatu maksud. Pemilihan kata yang tepat bertujuan untuk memberikan kesan serta pesan agar mudah diterima oleh lawan bicara.

Diksi sangat berguna dalam penulisan karya tulis seperti kertas kerja, resume, laporan, dan sebagainya. Bagi seorang auditor atau akuntan, laporan yang baik adalah yang mampu menyampaikan data sesuai kenyataan dengan menggunakan bahasa yang tepat. Oleh karena itu, kemampuan yang mendukung hal tersebut adalah penguasaan diksi yang baik. Untuk sebuah laporan audit, diksi dipergunakan untuk menyatakan kata-kata mana yang dipakai untuk mengungkapkan suatu ide atau gagasan, termasuk di dalamnya untuk menyampaikan apa pun yang ada di dalam temuan data.

Dengan penguasaan diksi atau pilihan kata maka mahasiswa yang sedang berlatih menjadi auditor dapat membedakan secara tepat nuansa makna sesuai dengan gagasan yang ingin disampaikannya dan kemampuan tersebut hendaknya disesuaikan dengan 
situasi dan nilai rasa yang dimiliki oleh sekelompok masyarakat dan pendengar atau pembaca atau pengguna jasa laporan auditnya atau akuntan publiknya. Diksi yang tepat dapat mengekspresikan ide atau gagasan dan perasaan berikut proses dan tindakan yang melatarbelakanginya. Dalam beberapa berita terdapat fakta bahwa hasil audit atau hasil analisis akuntan publik terkadang menjadi masalah karena ada ketidakpahaman antara pengguna jasa dan penyedia jasa. Hal tersebut terjadi karena adanya kesalahan penggunaan diksi dalam penulisan laporan.

Beberapa penelitian terkait yang mendukung penelitian ini seperti dalam penelitian Sari (2017) disimpulkan bahwa keterampilan berkomunikasi berpengaruh positif terhadap kesempatan bekerja mahasiswa, dan kemampuan berbicara kepada publik berpengaruh positif terhadap kesempatan bekerja. Dikatakan pula dalam kesimpulan Lie dan Darmasetiawan (2017) bahwa soft skill memiliki pengaruh yang signifikan terhadap kesiapan kerja dalam menghadapi MEA pada mahasiswa. Pengaruh yang ditimbulkan bersifat positif yang berarti bahwa semakin tinggi soft skill yang dimiliki maka akan semakin tinggi pula tingkat kesiapan kerja dalam menghadapi MEA pada mahasiswa. Iriani (2017) menyimpulkan bahwa untuk kemampuan interpersonal skill mahasiswa memerlukan pelatihan seperti character building dan memasukan mata kuliah soft skill sebagai bekal untuk mempersiapkan lulusan agar memiliki kemampuan soft skill yang diharapkan dunia kerja.

Pengaruh diksi dalam penelitian Cahyati (2009) menyimpulkan bahwa siswa yang memiliki tingkat penguasaan diksi yang tinggi memiliki skor nilai yang lebih baik jika dibandingkan dengan siswa yang memiliki tingkat penguasaan diksi yang sedang atau rendah. Walaupun terbiasa dengan penulisan makalah, tidak semua mahasiswa mampu menggunakan kata-kata yang sesuai dengan penggunaannya. Dalam penulisan makalah, kata-kata yang digunakan berbeda dengan kata-kata yang digunakan dalam keseharian (Halimatussakdiah dan Situmorang, 2013). Penelitian Homsaniwati (2018) membuktikan bahwa terdapat pengaruh yang signifikan pada kecerdasan interpersonal dan penguasaan diksi secara bersama-sama terhadap kemampuan menulis, serta terdapat pengaruh yang signifikan pada penguasaan diksi terhadap kemampuan menulis.

Selain bahasa tulisan, bisa saja kesalahan terjadi dalam bahasa lisan. Hal tersebut terjadi pada saat negosiasi. Sebuah negosiasi adalah suatu proses diskusi yang dilakukan demi menyelesaikan suatu masalah dengan cara yang bisa diterima oleh pihak lain yang 
melakukan negosiasi. Dalam kegiatan negosiasi, setiap pihak akan mencoba untuk merujuk pihak lainnya untuk menyetujui sudut pandangnya. Dengan bernegosiasi, setiap pihak yang terlibat akan berusaha utuk menghindari perdebatan atau pertengkaran dan menyepakati suatu wujud komporomi.

Negosiasi adalah suatu wujud interaksi sosial yang terjalin antara beberapa pihak untuk mencapai kesepakatan bersama yang dinilai saling menguntungkan untuk setiap pihak. Mereka yang melakukan negosiasi ini biasa disebut dengan negosiator. Kemampuan seorang mahasiswa calon auditor atau akuntan harus mampu menguasai negosiasi karena salah satu tujuan negosiasi adalah mendapatkan kesepakatan yang dinilai saling menguntungkan, menyelesaikan masalah, dan mendapatkan solusi atas setiap masalah yang dialami pihak yang bernegosiasi, serta untuk mendapatkan kondisi yang saling menguntungkan bagi setiap pihak yang bernegosiasi.

Jika seorang mahasiswa akuntansi menguasai diksi maka dia dapat membedakan makna denotasi dan konotasi dengan cermat agar apa yang disampaikan dalam komunikasi tersebut lugas dan tidak bermakna ganda. Dengan penggunaan sinonim dalam penguasaan diksi maka banyak kosa kata yang dipergunakan baik dalam bahasa tulisan maupun bahasa lisan.

Pada saat bernegosiasi, mahasiswa dapat menggunakan diksi yang cermat tanpa tertukar. Mahasiswa pun terlatih untuk tidak menafsirkan makna kata secara subjektif berdasarkan pendapat sendiri. Jika ada pemahaman yang belum dapat dipastikan, maka cari makna yang tepat dalam kamus, misalnya: 'modern' sering diartikan secara subjektif. Mahasiswa pun mampu menggunakan imbuhan asing secara tepat, misalnya: 'dilegalisir' seharusnya 'dilegalisasi', 'koordinir' seharusnya 'koordinasi'.

Beberapa manfaat dari negosiasi adalah terciptanya jalinan kerja sama antarpihak untuk memperoleh tujuan masing-masing, terjadinya rasa saling pengertian pada setiap pihak yang bernegosiasi terkait kesepakatan yang akan ditempuh dan efeknya untuk pihak-pihak tersebut, terjalinnya kesepakatan bersama yang saling menguntungkan, dan terciptanya interaksi yang positif pada setiap pihak yang bernegosiasi. Dengan adanya penguasaan diksi diharapkan mahasiswa akuntansi yang menjadi calon auditor dan akuntan tidak akan menimbulkan interpretasi yang berlainan antara penulis laporan atau pembicara dengan pembaca laporan atau pendengar, adapun kesesuaian kata bertujuan agar tidak merusak suasana serta menghaluskan kata dan kalimat agar lebih berterima. 


\section{Komunikasi dalam Tim pada Kinerja Auditor}

Hasil positif lain dari kemampuan soft skill komunikasi bagi mahasiswa calon auditor adalah adanya tim audit yang dibentuk secara berjenjang dan terdiri atas beberapa individu (senior, supervisor, dan manajer) yang bekerja sama dengan tujuan untuk melaksanakan audit. Seorang mahasiswa yang belajar menjadi auditor pada saat bekerja sebagai tim artinya melakukan kerja dengan menjalankan pengiriman informasi oleh salah seorang anggota kelompok kepada anggota yang lain dengan menggunakan simbolsimbol tertentu. Beberapa penelitian bahkan telah menunjukkan bahwa komunikasi mempunyai implikasi penting terhadap kepuasan kerja. Komunikasi yang terjalin di antara anggota tim audit menjadi aktivitas yang sangat penting untuk mencapai hasil akhir, yaitu opini audit. Dalam banyak literatur audit, komunikasi dalam tim terbukti berpengaruh positif dan signifikan pada kinerja auditor.

Dalam hal komunikasi serta melakukan negosiasi, mahasiswa akuntansi yang akan berprofesi sebagai auditor dan akuntan menggunakan penguasaan diksi yang baik dengan sejumlah kriteria yang telah diketahui dari adanya mata kuliah Bahasa Indonesia dalam materi diksi. Penggunaan diksi yang sesuai ketentuan serta banyaknya latihan akan menjadikan penguatan soft skill bidang komunikasi dan negosiasi akan tercapai atau terpenuhi dengan baik.

Diksi diperoleh dari banyaknya membaca kajian bidang ilmu akuntansi karena ranah diksi mengutamakan bidang yang dipelajari meskipun tidak menutup kemungkinan untuk mempelajari semua bidang ilmu. Seringnya menggunakan diksi yang benar akan menjadi kebiasaan baik dalam melakukan komunikasi dan negosiasi yang bermanfaat dan berdaya guna bagi bidang kerja yang akan dimasuki oleh seorang mahasiswa akuntansi.

\section{KESIMPULAN DAN SARAN}

\subsection{Kesimpulan}

Sebagai mahasiswa akuntansi yang diharapkan dapat menjawab tantangan memiliki skill auditor di era revolusi industri 4.0 yang kompeten, tidak cukup hanya mengandalkan hard skill saja, maka pengembangan soft skill yang diperoleh dari mata kuliah Bahasa Indonesia yang menjadi bagian dari interpersonal skills, yaitu komunikasi efektif dan negosiasi dapat diperoleh melalui penguasaan diksi. Melalui penguasaan diksi yang terus dilatih dalam menuliskan serta mempresentasikan laporan tugas di perkuliahan 
maka kemampuan komunikasi efektif dan negosiasi akan dikuatkan. Hal tersebut sejalan dengan adanya Ketentuan Mendikbud 84/E/Kpt/2020 yang menyatakan bahwa tujuan mata kuliah Bahasa Indonesia adalah melaporkan hasil penelitian dan hasil kegiatan. Mahasiswa yang mampu menguasai diksi yang baik akan memiliki kesempatan menggunakan soft skill komunikasi efektif dan negosiasi yang dapat dipergunakan pada saat memasuki dunia lapangan kerja sesungguhnya.

\subsection{Saran}

Dalam menambah kajian tentang penguatan interpersonal skill mahasiswa akuntansi, selain komunikasi efektif dan negosiasi, akan lebih baik lagi jika sekaligus dikaitkan dengan intra-personal skill yang membutuhkan character building dan creative thinking yang keduanya juga dipelajari melalui mata kuliah Bahasa Indonesia sebagai mata kuliah alat di perguruan tinggi.

\section{DAFTAR PUSTAKA}

Cahyawati, Rina Susi. 2009. Pengaruh Penerapan Model Pembelajaran Kooperatif Tipe Teams Games Tournaments dan Penguasaan Diksi terhadap Kemampuan Menulis Teks Berita Siswa Kelas VIII Smp Negeri 2 Polanharjo dalam Upt Perpustakaan UNS https://Digilib.Uns.Ac.Id/Dokumen/Detail/5354/Pengaruh-PenerapanModel-Pembelajaran-Kooperatif-Tipe-Teams-Games-Tournaments-Dan-

Penguasaan-Diksi-Terhadap-Kemampuan-Menulis-Teks-Berita-Siswa-KelasViii-Smp-Negeri-2-Polanharjo.

Dewi, Luh Gede Kusuma Dewi dan Dewi, Nyoman Ayu Wulan. 2020. Profesi Akuntansi di Era New Normal: Apa yang Harus Dipersiapkan? Jurnal Akuntansi Profesi Vol. 11 NO.2 Desember 2020 p-ISSN:2338-6177 e-ISSN: 2686-2468.

DPN IAI. 2016. Kode Etik Akuntan Profesional dalam http://iaiglobal.or.id/v03/files/fileberita/KODE-ETIK-2016.pdf

Fuadiyah, Ellya, Sukesti, Fatmasari. 2013. Analisis Faktor-Faktor yang Mempengaruhi Mahasiswa dalam Memahami Mata Kuliah Auditing (Studi Empiris pada Mahasiswa Jurusan Akuntansi di Fakultas Ekonomi Unimus dan Unissula Semarang). MAKSIMUM Vol. 3, No. 2, Maret 2013-Agustus 2013.

Halimatussakdiah, Situmorang, Grace. 2013. Penggunaan Diksi dalam Penulisan Makalah pada Mahasiswa Jurusan Pendidikan Akuntansi. School Education Journal Pgsd Fip Unimed Vol 1, No 1 (2013).

Hernawati, Nopi, Maemunah, Mey, Kuntorini, Ririn Sri. 2019. Pengaruh Hardskill Mahasiswa Akuntansi terhadap Kompetensi Auditor Era Revolusi Industri 4.0. KAJIAN AKUNTANSI Universitas Islam Bandung Volume 22 No. 1, tahun 2021. 
Homsaniwati. 2018. Pengaruh Kecerdasan Interpersonal dan Penguasaan Diksi Terhadap Kemampuan Menulis Cerita Pendek. Diskursus: Jurnal Pendidikan Bahasa Indonesia Vol. 1, No. 2, Agustus 2018, Pp. 136-145 P-Issn: 2615-4935 E-Issn: 2615-4943.

Iriani, Tuti. 2017. Studi Analisis Terhadap Kemampuan Softskills Mahasiswa Fakultas Teknik UNJ. Jurnal Pendidikan Teknik Sipil Volume 6, No 1, Februari 2017.

Keputusan Direktur Jenderal Pendidikan Tinggi Kementrian Pendidikan dan Kebudayaan Republik Indonesia Nomor 84/E/KPT/2020 tentang Pedoman Pelaksaan Mata kuliah Wajib pada Kurikulum Pendidikan Tinggi, 19 Oktober 2020, dalam https://lldiktil.ristekdikti.go.id/berkas/kepdirjen-dikti-nomo-84_e_kpt_2020tentang-pedoman-pelaksanaan-mata-kuliah-wajib-pada-kurikulum-pendidikantinggi.pdf

Keraf, Gorys. 2010. Diksi dan Gaya Bahasa. Jakarta: Gramedia.

Kuntorini, Ririn Sri, Djajasudarma, Fatimah, Wahya. 2013. Penggunaan Flouting dalam Tayangan Humor Opera Van Java. FIB Unpad.

Kuntorini, Ririn Sri, Pradana, Mahaputra Aditya. 2014. Penggunaan Flouting dalam Prinsip Kerja Sama sebagai Cermin Budaya Kontemporer. Jurnal Sosioteknologi Volume 13, Nomor 3.

Lie, Novia Lucas Cahyadi, Darmasetiawan, Noviaty Kresna. 2017. Pengaruh Soft Skill terhadap Kesiapan Kerja Menghadapi Masyarakat Ekonomi Asean pada Mahasiswa S1 Fakultas Bisnis dan Ekonomika Universitas Surabaya. Calyptra: Jurnal Ilmiah Mahasiswa Universitas Surabaya Vol.6 No.2 (2017).

Nevada, Cindy. 2021. Peluang Kerja Gelar Sarjana Akuntansi dalam https://gokampus.com/blog/peluang-kerja-gelar-sarjana-akuntansi/diakses pada 9 April 2021.

Palupi, Sri. 2011. Upaya Membangun Karakter (Soft Skills) Mahasiswa Bidang Boga dalam staffnew.uny.ac.id.

Pusat Bahasa Departemen Pendidikan Nasional. 2006. Kamus Besar Bahasa Indonesia. Jakarta: Balai Pustaka.

Riswanti, Hanum Atika. 2010. Pengaruh Kemampuan Komunikasi, Berpikir Kritis, dan Kepribadian terhadap Pemahaman Akuntansi Mahasiswa. Jawa Timur: Fakultas Ekonomi Universitas Pembangungan Nasional "Veteran".

Tarigan, Guntur Henry. 2008. Menulis, Sebagai Suatu Keterampilan Berbahasa. Bandung: Angkasa.

Bandung: Angkasa.

Sari, Rita. 2017. Soft Skills Mahasiswa Pendidikan Akuntansi Fakultas Keguruan dan Ilmu Pendidikan Universitas Muhammadiyah Surakarta Angkatan 2014 terhadap Kesempatan Bekerja. Surakarta: Universitas Muhammadiyah Surakarta.

Solin, Mutsyuhito. 2010. Peranan Bahasa Indonesia dalam Membangun Karakter Bangsa. Jurnal Unimed No. 82 Th 38. 
Sugiyono. 2012. Statistika untuk Penelitian. Bandung: Alfabeta.

---------. 2015 Metode Penelitian Pendidikan. Bandung: Alfabeta.

---------. 2017. Metode Penelitian Pendidikan Pendekatan Kualitatif, Kuantitatif dan $R \& D$. Bandung: Alfabeta.

Quipper.com. 2020. Macam-Macam Jurusan Kuliah Anti Nganggur, Dijamin Masa Depan Cerah dalam https://www.quipper.com/id/blog/quipper-campus/campuslife/n-jurusan-kuliah-anti-nganggur.

Waridah. 2016. Berkomunikasi dengan Berbahasa yang Efektif dapat Meningkatkan Kinerja. Jurnal Simbolika/Volume 2/Nomor 2/ Oktober 2016. 